\title{
PENGARUH PEMBERIAN DIET TINGGI KARBOHIDRAT DIBANDINGKAN DIET TINGGI LEMAK TERHADAP KADAR TRIGLISERIDA DAN HDL DARAH PADA Rattus novergicus galur wistar
}

\section{THE INFLUENCE OF HIGH-CARBOHYDRATE DIET ADMINISTRATION IN COMPARISON WITH HIGH-FAT DIET TOWARD TRIGLYCERIDE AND HDL LEVEL IN BLOOD ON Rattus novergicus strain wistar}

\author{
Iva Tsalissavrina *, Djoko Wahono **, Dian Handayani * \\ * IImu Gizi Kesehatan Fakultas Kedokteran Universitas Brawijaya \\ ** Laboratorium IImu Penyakit Dalam Fakultas Kedokteran Universitas Brawijaya/ RSU dr. Saiful Anwar Malang
}

\begin{abstract}
The improving social welfare and food availability has created a shift of consumption pattern that leads to high-fat foods and low-complex carbohydrate, especially the fibrous foods. As we know,carbohydrate has been considered as the safe component of foods, therefore, it is recommended to be consumed more. Recently, more experts have started to think about the role of carbohydrate and the emergence of atherosclerosis. The Purpose of the research was to know the risk of high carbohydrate diet application compared to high fat blood triglyceride diet content and high Density Lipoprotein. Complete random design and Post Test Only Control Group was used in this research. Statistic test one way Anova was used to know the difference resulted from diet aplication, and the situation of the difference continued by Tukey Test. The Value of Triglyceride is measured by using Calorimetric Enzymatic test - Glycerol 3 Phosphate -oxidase methods and the value of HDL is measured by using Cholesterol Hydrolise - oxidase methods. The result showed that the highest value of triglyceride were on the high fat diet group ( $169 \mathrm{mg} / \mathrm{dl}$ ), followed by high carbohydrate diet (130,2 $\mathrm{mg} / \mathrm{dl})$ and the lowest was normal diet $(81,2 \mathrm{mg} / \mathrm{dl})$. The lowest value of $\mathrm{HDL}$ were on the normal diet group $(32,7 \mathrm{mg} / \mathrm{dl})$, followed by high fat diet $(34,2 \mathrm{mg} / \mathrm{dl})$ and the highest was high carbohydrate diet $(38,4 \mathrm{mg} / \mathrm{dl})$. The result of the statistical test over the value of Triglyceride showed a significant difference $(P=0,011)$.For $H D L$ level, it showed insignificant difference on each treatment $(P=0.111)$. Based on the result, the high carbohydrate diet increases the value of triglyceride, so the suggestion is to pay attention to carbohydrate percentage which we consume in food.
\end{abstract}

Key words: high-carbohydrate diet, high-fat diet, Triglyceride, HDL, Rattus novergicus strain wistar

\section{PENDAHULUAN}

Meningkatnya kesejahteraan penduduk dan ketersediaan pangan mengakibatkan terjadinya perubahan pola konsumsi yang mengarah ke jenis-jenis makanan yang kaya lemak tetapi rendah karbohidrat komplek, khususnya serat pangan (1).

Menurut Sastroamidjojo (2000), perubahan pola hidup meliputi pola makan. Aktifitas dan kebiasan hidup seperti merokok dan stress merupakan faktor resiko untuk terjadinya penyakit pembuluh darah (2). Aterosklerosis, sebagai gangguan pada pembuluh darah koroner merupakan akibat penimbunan plaque lipida dalam dinding arteri. Beberapa faktor yang dapat meningkatkan resiko terjadinya Aterosklerosis adalah adanya peningkatan kadar lipid darah seperti peningkatan kadar LDL (Low Density Lipoprotein) darah, Kolesterol total dan Trigliserida darah serta penurunan HDL (High Density Lipoprotein) darah.

Jurnal Kedokteran Brawijaya, Vol. XXII, No.2, Agustus 2006 Korespondensi: Iva Tsalisavrina; IImu Gizi Kesehatan; jl. Veteran Malang 65145; Telp. (0341) 580993.
Peningkatan kadar kolesterol total dan LDL (Low Density Lipoprotein) darah dapat disebabkan oleh peningkatan konsumsi lemak jenuh dan kolesterol yang tinggi dalam makanan. Sedangkan peningkatan trigliserida darah atau hipertrigliserida dipengaruhi oleh faktor gen dan konsumsi makanan seperti Karbohidrat, lemak, dan alkohol. Karena itu untuk menurunkan kadar trigliserida darah selain lemak makanan, karbohidrat juga diperhitungkan. Selain itu, kadar trigliserida darah juga dipengaruhi oleh aktivitas enzim LPL (Lipoprotein Lipase) yang berfungsi untuk menghidralisis trigliserida menjadi asam lemak dan gliserol. Rendahnya aktifitas LPL ini akan dapat meningkatkan kadar trigliserida darah (3).

Terjadinya peningkatan kadar lemak darah dan obesitas serta resistensi insulin merupakan suatu sindroma metabolik yang memiliki kaitan erat dengan timbulnya aterosklerosis. Pengendalian dislipidemia dan penurunan berat badan tidak lepas dari pengaturan diet. Diet konvensional untuk penurunan berat badan yang selama ini direkomendasikan adalah pembatasan kalori dengan komponen rendah lemak dan tinggi karbohidrat. Selama ini 
karbohidrat dianggap sebagai komponen makanan yang aman sehingga direkomendasikan dalam prosentase yang lebih tinggi akan tetapi akhir-akhir ini banyak para ahli yang mulai memikirkan peran karbohidrat pada proses terjadinya aterosklerosis. Kenyataan bahwa angka kejadian penyakit kardiovaskuler juga cukup tinggi di negara yang kandungan utama dari makanannya adalah karbohidrat. Hal ini menguatkan dugaan dari para ahli bahwa karbohidrat mempunyai peranan cukup tinggi dalam kejadian aterosklerosis (4).

Penelitian yang dilakukan oleh Samaha dkk, terhadap 132 wanita obese yang dibagi dalam dua kelompok,satu kelompok diberi diet rendah karbohidrat dengan kalori tak terbatas sedangkan kelompok kedua diberi diet rendah lemak dengan pembatasan kalori. Hasil yang didapatkan setelah 6 bulan penelitian adalah penurunan berat badan dan pengurangan berat badan dan penurunan trigliserida lebih besar pada kelompok diet rendah karbohidrat dibandingkan kelompok diet rendah lemak.

Stephen (2003), dalam penelitian terhadap pengaruh pemberian diet tinggi karbohidrat dan lemak jenuh ternyata dapat meningkatkan kadar trigliserida dalam tubuh dan bisa menyebabkan beberapa kondisi medis seperti Diabetes Mellitus, Hipotiroid dan gangguan ginjal. Beberapa studi menunjukan hubungan trigliserida dengan penyakit jantung (5). Kenaikan kadar trigliserida ini akan mempengaruhi vikositas dari sel darah merah dan kondisi ini akan berakibat terjadinya penyakit jantung koroner. Rasio antara Trigliserida dan HDL merupakan parameter yang lebih baik untuk mengetahui kemungkinan serangan penyakit jantung daripada perbandingan antara LDL dengan HDL.

Dengan melihat permasalahan di atas, ingin dilihat dan dikaji pengaruh pemberian diet tinggi karbohidrat dibandingkan pemberian diet tinggi lemak terhadap kadar trigliserida dan HDL darah pada hewan coba rattus novergicus galur wistar. Apakah diet tinggi Karbohidrat lebih meningkatkan kadar trigliserida dan menurunkan kadar HDL darah dibandingkan Diet tinggi lemak?

\section{METODE}

\section{Desain Penelitian}

Desain penelitian ini adalah Experimental Laboratorik dengan menggunakan jenis Randomized control group post test design (6). Hewan coba yang digunakan adalah tikus jantan jenis Rattus novergicus Galur Wistar. Hewan coba dibagi atas 3 kelompok, yaitu kelompok $A$ untuk perlakuan diet tinggi karbohidrat, kelompok $B$ untuk perlakuan diet tinggi lemak dan kelompok $\mathrm{C}$ dengan pemberian diet normal sebagai kontrol (7).

a. Kriteria inklusi : (1)Tikus jenis Rattus novergicus galur wistar, (2) Jenis kelamin jantan, (3) Umur \pm 3 bulan,
(4) Berat 100 - 150 gram, (5) Warna bulu putih, dan

(6) Tikus aktif

b. Kriteria eksklusi adalah Tikus yang tidak mau makan dan Tikus yang mengalami penurunan keadaan fisik atau mati

Jumlah sampel

$$
n \geq 16(p-1)
$$

Keterangan : $n=$ jumlah sampel

$P=$ jumlah perlakuan

Jumlah sampel masing-masing kelompok 7

Variabel terikat dalam penelitian eksperimental merupakan respons subjek penelitian terhadap perlakuan yang diberikan. Dalam penelitian ini yang termasuk variabel terikat adalah kadar Trigliserida dan kadar HDL darah pada hewan coba.

Variabel bebas dalam penelitian eksperimental adalah perlakuan, sehingga variabel bebas dalam penelitian ini adalah diet Tinggi Karbohidrat dan diet tinggi lemak.

Variabel kendali adalah variabel yang dikendalikan oleh peneliti agar subjek penelitian berupa hewan coba tikus dalam keadaan homogen. Pengendalian yang dilakukan adalah dengan cara inklusi dan eksklusi, yaitu hewan coba yang memenuhi syarat dimasukan (inklusi) dalam sampel penelitian, sedangkan yang tidak memenuhi syarat dikeluarkan (eksklusi) dari penelitian.

\section{Cara Pengumpulan Data}

Data yang dikumpulkan meliputi :

1. Data berat badan tikus yang diperoleh dari hasil penimbangan berat badan tikus menggunakan timbangan merk sartorius Melter dengan ketelitian 0,1 Kg tiap minggu sekali.

2. Data asupan makanan perhari dihitung dengan menimbang sisa makanan yang diberikan pada hewan coba setiap harinya menggunakan timbangan merk sartorius Melter dengan ketelitian 0,1 Kg.

3. Data kadar Trigliserida dalam serum sampel diukur setelah 12 minggu perlakuan, serum darah sampel yang diperiksa dengan menggunakan metode Calorimetric Enzymatic test - Glycerol 3 Phosphate oxidase (GPO) dengan satuan $\mathrm{mg} / \mathrm{dl}$, dibaca pada panjang gelombang $500 \mathrm{~nm}$ dengan menggunakan spektrofotometer Hitachi. Batas normal kadar trigliserida darah tikus adalah $26-145 \mathrm{mg} / \mathrm{dl}(8)$.

4. HDL darah diperiksa dengan metode Cholesterol Hydrolise - oxidase (CHOD-PAP) dengan satuan mg/dl dan dibaca pada panjang gelombang $500 \mathrm{~nm}$ dengan menggunakan spektofotometer Hitachi.

Komposisi pakan tikus dapat dilikat pada Tabel 1. 
Tabel 1. Komposisi Pakan Tikus

\begin{tabular}{cccc}
\hline Bahan & Diet Normal & Diet Tinggi Karbohidrat & Diet Tinggi Lemak \\
\hline Confeed Pars (gr) & 200 & 200 & 200 \\
Terigu (gr) & 100 & 100 & 100 \\
Glukosa (gr) & - & 80 & - \\
Kolesterol (gr) & - & - & 8 \\
Cholic Acid (gr) & - & - & 0.8 \\
Minyak Babi (gr) & - & - & 20 \\
Air (ml) & 71,2 & menyesuaikan & 71.2 \\
\hline
\end{tabular}

\section{Pemberian Perlakuan}

Dua puluh satu (21) ekor tikus wistar jantan umur 12 minggu, selanjutnya dibagi atas 3 kelompok secara acak. Yaitu kelompok diet normal (7 ekor), kelompok diet tinggi Karbohidrat (7 ekor) dan kelompok diet tinggi lemak (7 ekor). Masing-masing kelompok diberi diet iso kalori selama 12 minggu kemudian dilakukan pembedahan dan dilakukan pemeriksaan kadar Trigliserida dan HDL .

\section{Analisis Data}

Data dianalisa dengan menggunakan uji statistik dengan menggunakan uji Anova One Way. Kemudian data yang didapat diolah secara komputerisasi dengan menggunakan program SPSS 11.00. Uji lanjutnya menggunakan uji Post Hoc Tukey untuk melihat perbedaan dari tiap kelompok. Bermakna bila $\mathrm{P} \leq 0,05$.

\section{HASIL PENELITIAN}

Karakteristik Sampel

Pada penelitian ini didapatkan karakteristik sampel yaitu tikus percobaan Rattus novergicus galur wistar seperti pada Tabel 2.

\section{Asupan Energi}

Selama penelitian, tikus wistar diberikan diet isokalori yaitu sekitar 104,6 - 104,8 kalori/ekor/hari. Asupan ini dilihat dari selisih jumlah pakan yang diberikan dengan sisa pakan yang ada per ekor per hari.

Hasil rata-rata asupan energi dari sampel hewan coba menunjukan nilai tertinggi ada pada kelompok diet normal yaitu 90,69 $\pm 12,47$ kalori/hari atau $86 \%$ dari energi pakan I hari yang diberikan. Sedangkan diet tinggi karbohidrat hanya mencapai rata-rata asupan energi 55,90 $\pm 30,23 \mathrm{kal} / \mathrm{hari}$ atau $52 \%$ dari kalori pakan yang diberikan, dan diet tinggi lemak mencapai 80,6 \pm 13,28 kal/hari atau $76 \%$ dari total energi pakan yang diberikan.

Uji statistik Anova One Way menunjukan perbedaan asupan energi antar kelompok diet signifikan $(p=0,000)$, sedangkan uji statistik lanjut menggunakan Post Hoc Tukey menunjukan perbedaan diet terhadap asupan energi baru terlihat pada kelompok diet normal dan diet tinggi lemak.

Rata - rata asupan energi antar perlakuan dapat dilihat pada Gambar 1.

Tabel 2. Data Karakteristik Tikus Wistar

\begin{tabular}{|c|c|c|c|c|}
\hline Kelompok & Diet Normal & Diet Tinggi Karbohidrat & Diet Tinggi Lemak & Signifikansi (P) \\
\hline n (jumlah sampel) & 7 & 7 & 7 & - \\
\hline Usia (bulan) & Jantan & Jantan & Jantan & - \\
\hline Berat badan awal (gram) & \pm 3 & $\begin{array}{c} \pm 3 \\
1220+667\end{array}$ & $\begin{array}{l} \pm 3 \\
212\end{array}$ & $P_{0}=0322$ \\
\hline & & $122.9 \pm 6.67$ & $116.2 \pm 12.2$ & $\begin{array}{l}P_{0}=0.332 \\
P_{1}=0.187 \\
P_{2}=0.927\end{array}$ \\
\hline Berat badan akhir (gram) & $312.1 \pm 59.9$ & $255.8 \pm 34.9$ & $282.2 \pm 27.6$ & $\begin{array}{l}P_{0}=0.049 \\
P_{1}=0.446 \\
P_{2}=0.399\end{array}$ \\
\hline Kenaikan BB (gram) & $183,6 \pm 49,3$ & $132,9 \pm 31,8$ & $165,74 \pm 19,9$ & $\begin{array}{l}P_{0}=0.059 \\
P_{1}=0.658 \\
P_{2}=0.278\end{array}$ \\
\hline
\end{tabular}

Keterangan :

Po = Signifikansi antara diet normal dengan Diet Tinggi karbohidrat; P1 = signifikansi antara diet normal dengan diet tinggi lemak; P2 = signifikansi antara diet tinggi karbohidrat dengan diet tinggi lemak . 
Tabel 3. Data Hasil Penelitian Tikus Wistar pada Masing-Masing Kelompok Diet

\begin{tabular}{|c|c|c|c|c|}
\hline Kelompok & Diet Normal & $\begin{array}{l}\text { Diet Tinggi } \\
\text { Karbohidrat }\end{array}$ & $\begin{array}{l}\text { Diet Tinggi } \\
\text { Lemak }\end{array}$ & Signifikansi (P) \\
\hline Asupan Energi (kkal) & 90.6912 .47 & 55.9030 .23 & 80.613 .28 & $\begin{array}{l}P_{0}=0.000 \\
P_{1}=0.082 \\
P_{2}=0.000 \\
P_{0}=0.053\end{array}$ \\
\hline $\begin{array}{l}\text { Trigliserida Serum } \\
(\mathrm{mg} / \mathrm{dl})\end{array}$ & $81,2 \pm 17,78$ & $130,2 \pm 42,03$ & $169 \pm 43,49$ & $P_{1}=0.001$ \\
\hline & & & & $\begin{array}{l}P_{2}=0.143 \\
P_{0}=0.106\end{array}$ \\
\hline HDL serum (mg/dl) & $32,7 \pm 3,86$ & $38,4 \pm 2,76$ & $34,2 \pm 7,13$ & $\begin{array}{l}P_{1}=0.825 \\
P_{2}=0.285 \\
P_{0}=0.000\end{array}$ \\
\hline $\begin{array}{l}\text { Gula Darah Puasa } \\
(\mathrm{mg} / \mathrm{dl})\end{array}$ & $184,8 \pm 43,02$ & $293,5 \pm 31,26$ & $224,5 \pm 37,08$ & $P_{1}=0.145$ \\
\hline & & & & $P_{2}=0.08$ \\
\hline
\end{tabular}

Keterangan :

Po = Signifikansi antara diet normal dengan Diet Tinggi karbohidrat $; \mathrm{P} 1=$ signifikansi antara diet normal dengan diet tinggi lemak ; P2 = signifikansi antara diet tinggi karbohidrat dengan diet tinggi lemak

Tabel 4. Data Kandungan Energi dan Zat Gizi dalam Pakan Tikus Wistar pada Masing-Masing Kelompok Diet

\begin{tabular}{cccc}
\hline Kelompok & Diet Normal & Diet Tinggi Karbohidrat & Diet Tinggi Lemak \\
\hline Energi ( kkal) & 104,62 & 104,70 & 104,78 \\
Karbohidrat (gram) & 18,05 & 21,05 & 14,58 \\
Lemak (gram) & 1,13 & 0,63 & 3,5 \\
Protein (gram) & 5,56 & 3,67 & 3,73 \\
Berat pakan (gram/hari) & 30,50 & 30,00 & 26,00 \\
\hline
\end{tabular}

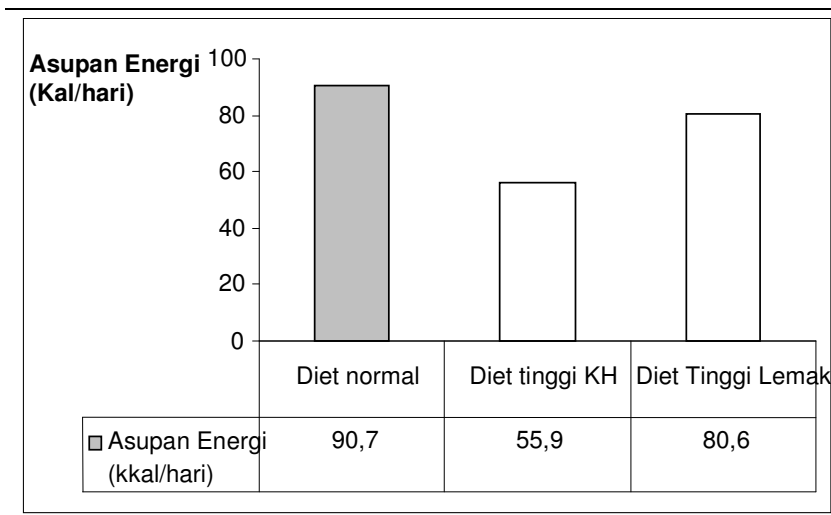

Gambar 1.Perbandingan Rata-rata Asupan Energi Tikus Wistar antar Masing-masing Kelompok Diet $(p=0,000)$

Asupan energi menunjukan kelompok diet normal menunjukan nilai asupan tertinggi dilanjutkan dengan kelompok diet normal dan yang terendah kelompok diet tinggi Karbohidrat.

\section{Berat Badan Tikus}

Penimbangan berat badan tikus dilakukan setiap 7 hari sekali sehingga dapat diketahui kenaikan berat badan secara bertahap. Kenaikan berat badan diketahui dengan menghitung selisih berat badan akhir dan awal penelitian. Berat badan awal dan berat badan akhir pada diet normal, diet tinggi karbohidrat dan diet tinggi lemak) disajikan dalam Gambar 2.

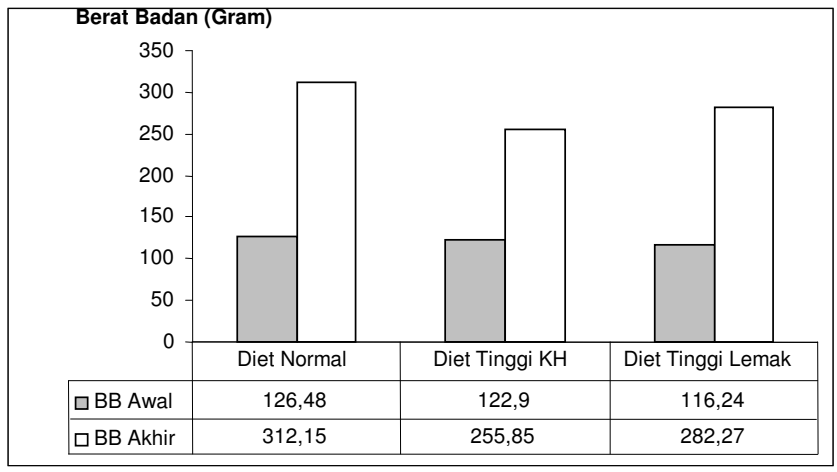

Grafik 2. Berat Badan tikus Masing-masing Kelompok Diet 
Dari gambar di atas dapat dilihat bahwa pada semua kelompok diet terdapat kenaikan berat badan dibandingkan berat badan awal tikus.Peningkatan berat badan pada kelompok diet normal lebih tinggi bila dibandingkan dengan kenaikan berat badan pada kelompok diet tinggi lemak ataupun diet tinggi karbohidrat. Adapun hasil yang diperoleh adalah pada kelompok perlakuan pemberian diet normal didapatkan kenaikan berat badan tikus 183,6 \pm 49,31 gram. Kelompok Tikus dengan perlakuan pemberian diet tinggi karbohidrat memiliki kenaikan berat badan 132,9 $\pm 31,8$ gram sedangkan pada perlakuan pemberian diet tinggi lemak memiliki kenaikan berat badan $166 \pm 19,9$ gram.

Berdasarkan hasil uji statistik one-way anova menunjukkan tidak adanya perbedaan yang signifikan pada berat badan awal tikus pada berbagai perlakuan pemberian pakan $(p=0,056)$. Hal ini menunjukan keseragaman berat badan awal hewan coba sebagai salah satu syarat inklusi sampel. Pada uji lanjut Tukey menunjukkan bahwa perbedaan baru terlihat pada pemberian diet normal .

\section{Pengaruh Diet terhadap kadar Trigliserida}

Pemeriksaan kadar trigliserida serum dari tikus wistar dilakukan pada akhir penelitian dan didapatkan hasil seperti pada Gambar 3.

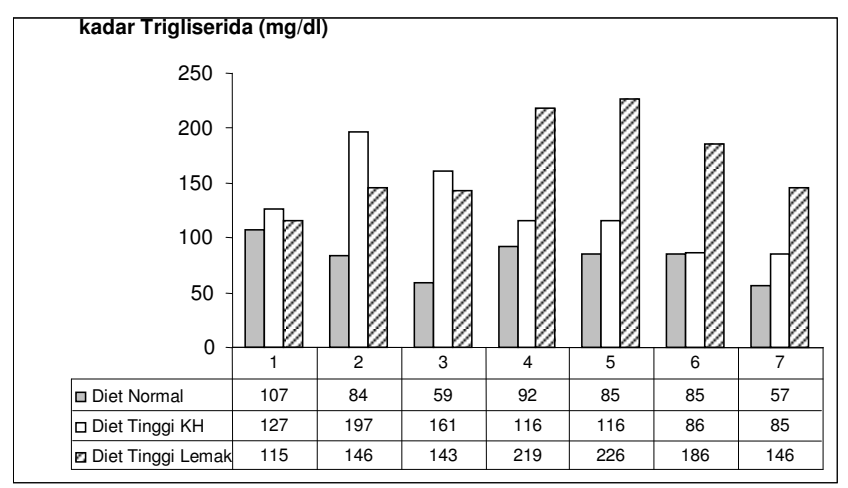

Berdasarkan data tersebut dapat diketahui rata-rata kadar trigliserida antar perlakuan seperti terlihat pada Gambar 4.

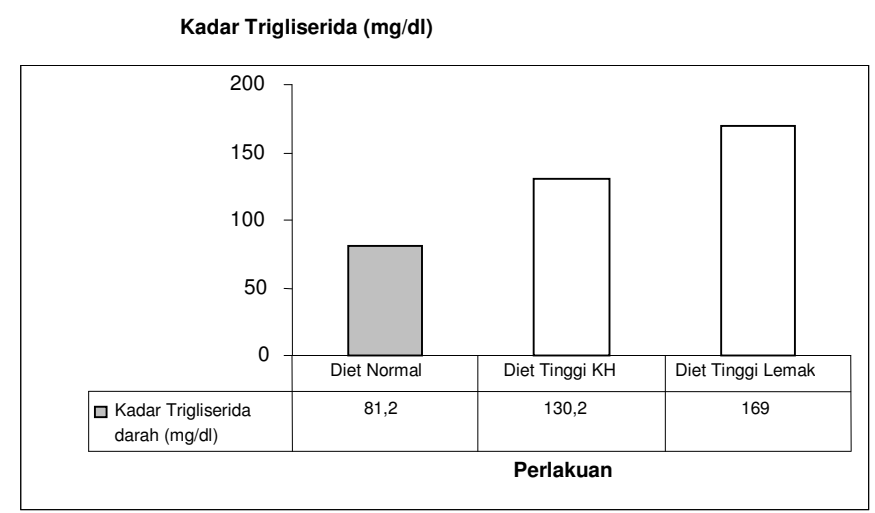

Gambar 4.Perbandingan Rata-rata Kadar Trigliserida Darah Tikus antar Masing-masing Kelompok Diet $(p=0.01)$

Gambar 4 menunjukan adanya perbedaan pada hasil pemeriksaan kadar trigliserida darah sample. Hasil pengujian kadar Trigliserida darah hewan coba untuk kelompok Diet Normal menunjukan rata-rata kadar trigliserida $81.28 \pm 17,98 \mathrm{mg} / \mathrm{dl}$. Selanjutnya pada kelompok diet tinggi karbohidrat menunjukan rata-rata kadar trigliserida $130.28 \pm 42,03 \mathrm{mg} / \mathrm{dl}$ dan nilai tertinggi adalah $169 \pm 43,49 \mathrm{mg} / \mathrm{dl}$ untuk kelompok diet tinggi lemak.

Hasil uji statistik One Way Anova menunjukan adanya perbedaan yang signifikan kadar trigliserida dari masing-masing kelompok. $(p=0.01)$.

Pengaruh diet terhadap Kadar HDL

Pemeriksaan kadar HDL serum dari tikus wistar dilakukan pada akhir penelitian dan didapatkan hasil seperti pada Gambar 5.

\section{Gambar 3. Rata-rata Kadar Trigliserida Masing-masing Kelompok Diet}

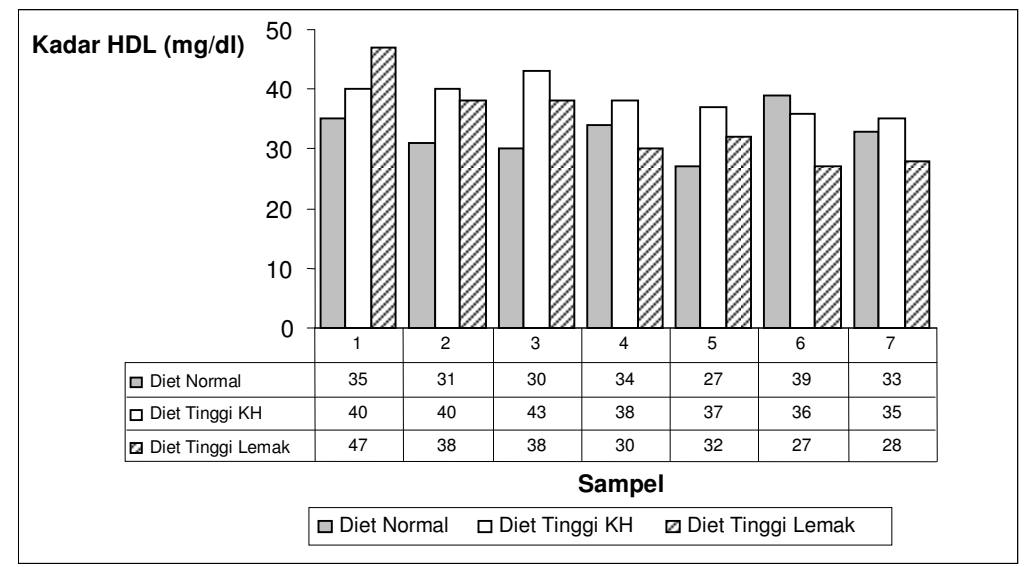

Gambar 5. Rata-rata Kadar HDL pada Masing-masing Kelompok Diet 


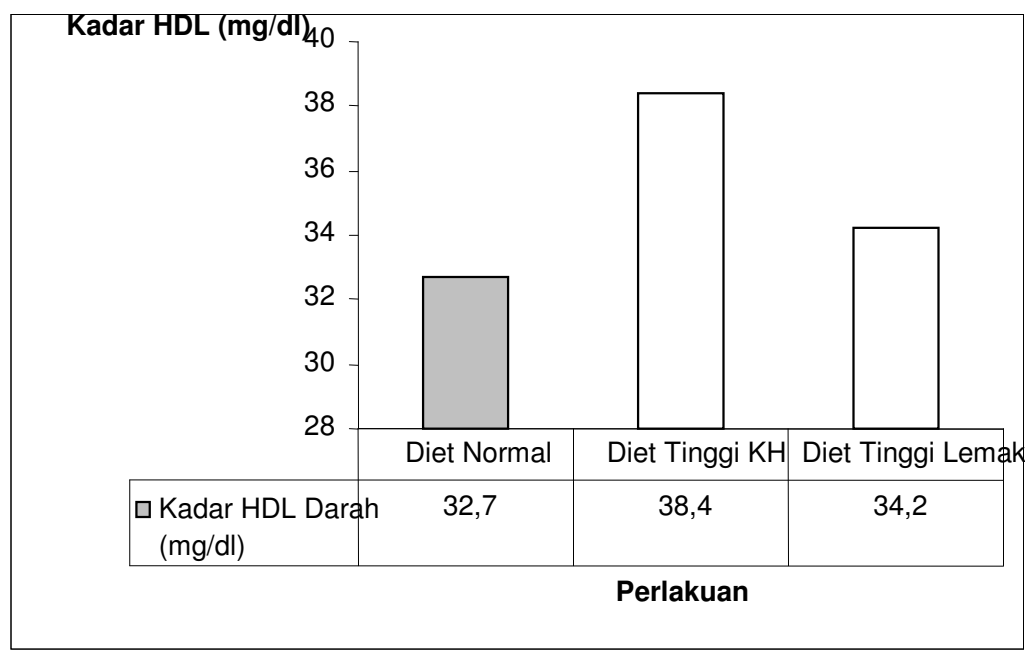

\section{Gambar 6. Perbandingan Rata-rata Kadar HDL antar Masing-masing Kelompok Diet $(p=0.11)$}

Gambar 6 menunjukan adanya perbedaan pada hasil pemeriksaan kadar HDL darah sampel. Hasil pengujian kadar HDL darah hewan coba untuk kelompok Diet Normal menunjukan rata-rata kadar $\mathrm{HDL} 32,7 \pm 3,86 \mathrm{mg} / \mathrm{dl}$. Selanjutnya pada kelompok diet tinggi karbohidrat menunjukan rata-rata kadar HDL 38,4 $\pm 2,76 \mathrm{mg} / \mathrm{dl}$ dan $34,2 \pm 7,13 \mathrm{mg} / \mathrm{dl}$ untuk kelompok diet tinggi lemak .

Namun demikian hasil uji statistik One Way Anova menunjukan bahwa hasil kadar HDL dari masing-masing kelompok perlakuan tersebut menunjukan tidak ada perbedaan yang bermakna atau $p=0.11$.

\section{DISKUSI}

\section{Pengaruh Diet terhadap Asupan Energi Sampel}

Hasil rata-rata asupan energi dari sample hewan coba menunjukan nilai tertinggi ada pada kelompok diet normal yaitu 90,69 $\pm 12,47$ kalori/hari atau $86 \%$ dari total kalori pakan/ hari yang diberikan. Kelompok diet tinggi karbohidrat mencapai rata-rata asupan energi 55,90 \pm $30,23 \mathrm{kal} / \mathrm{hari}$ atau $52 \%$ dari kalori pakan yang diberikan, dan diet tinggi lemak mencapai 80,6 $\pm 13,28 \mathrm{kal} / \mathrm{hari}$ atau $76 \%$ dari total energi pakan yang diberikan.

Dalam penelitian ini, digunakan asupan energi dan bukan tingkat konsumsi energi dikarenakan tidak adanya RDA (Recommended Dietary Allowance) atau standar kebutuhan nutrisi/hari untuk tikus terutama standar kebutuhan perhari untuk kalori, karbohidrat dan lemak.

Uji statistik Anova One Way menunjukan perbedaan asupan energi antar kelompok diet signifikan $(P<0.05)$, sedangkan uji statistik lanjut menggunakan Post Hoc Tukey menunjukan perbedaan diet terhadap asupan energi baru terlihat pada kelompok diet normal dan diet tinggi lemak. Asupan energi pada ketiga kelompok menunjukkan perbedaan.
Ada beberapa hal yang menyebabkan perbedaan ini di antaranya adalah dipengaruhi oleh daya terima sample yang dilihat dari sisa makan yang ada. Pada kelompok diet tinggi karbohidrat, asupan makanan lebih sedikit. Hal ini karena penggunaan glukosa yang tinggi sebagai salah satu sumber karbohidrat sederhana pada komposisi dietnya, menimbulkan penurunan nafsu makan pada kelompok diet tinggi karbohidrat.

Menurut Bruckdorfer (2005), glukosa yang tinggi akan menstimulasi pusat kenyang (satiety centre) yang terdapat pada nukleus ventromedial di hipotalamus dan sebaliknya, glukosa yang rendah, akan menstimulasi neuron pada pusat lapar (Feeding centre) yang terdapat pada nukleus lateral di hipotalamus (9). Stimulasi terhadap feeding centre ini berakibat pada peningkatan rasa lapar. Satiety centre berpengaruh terhadap timbulnya rasa kenyang setelah makan. Perasaan kenyang ini dikarenakan peningkatan kadar glukosa darah setelah kita makan menyebabkan bertambahnya glukosa yang melewati satiety centre dan mengaktifkannya. Tinggi rendahnya kadar glukosa darah yang berpengaruh terhadap aktivitas dari satiety centre ataupun feeding centre, dinamakan dengan teori glucostatic.

Pengaturan nafsu makan sama halnya dengan pengaturan berat badan juga dipengaruhi oleh aktivitas hormon Leptin. James (2005), menyatakan bahwa diet tinggi lemak akan menurunkan kadar Leptin yang lebih banyak dibandingkan diet tinggi karbohidrat (10). Leptin yang semakin rendah akan meningkatkan nafsu makan. Hal ini juga terlihat pada penelitian ini, kelompok diet tinggi lemak, mempunyai nafsu makan atau rata-rata asupan energi yang lebih tinggi yaitu $80,6 \pm 13,28 \mathrm{kal} / \mathrm{hari}$ atau $76 \%$ dari total kalori pakan yang disajikan dibandingkan kelompok diet tinggi karbohidrat yang hanya mencapai ratarata asupan energi $55,90 \pm 30,23 \mathrm{kal} / \mathrm{hari}$ atau hanya 52 
$\%$ dari total kalori pakan yang disajikan. Hal ini menjawab adanya implikasi hubungan antara diet tinggi lemak dengan kenaikan berat badan. Selain itu ternyata pemakaian fruktose akan lebih menurunkan kadar Leptin dibandingkan pemakaian glukosa.

\section{Pengaruh Diet Terhadap Berat Badan Sampel}

Hasil dari penelitian ini menunjukan adanya perubahan berat badan tikus/hewan coba dari saat awal sebelum perlakuan hingga akhir perlakuan. Perbedaan berat badan ini tidak lepas dari besar kecilnya asupan makan dari masing-masing kelompok percobaan. Pada penelitian ini, jumlah kalori pakan yang diberikan pada masing-masing kelompok diet a dalah iso kalori yaitu 104.6 kalori/ hari/ ekor tikus. Jumlah asupan makan dapat diketahui dari sisa pakan masing-masing hewan coba perhari. Setelah dilakukan pengamatan selama 12 minggu, asupan makan kelompok diet normal 90,69 $\pm 12,47$ kalori/hari atau $86 \%$ dari energi pakan / hari yang diberikan. Sedangkan diet tinggi karbohidrat hanya mencapai rata-rata asupan energi 55,90 \pm 30,23 kal/hari atau $52 \%$ dari kalori pakan yang diberikan, dan diet tinggi lemak mencapai 80,6 $\pm 13,28 \mathrm{kal} / \mathrm{hari}$ atau $76 \%$ dari total energi pakan yang diberikan.

Jumlah asupan makan paling banyak pada kelompok diet normal menyebabkan kenaikan berat badan yang paling tinggi pada kelompok ini bila dibandingkan kelompok diet lainnya. Demikian halnya asupan makan yang lebih tinggi dari kelompok diet tinggi lemak dibandingkan diet tinggi karbohidrat menyebabkan kenaikan berat badan yang lebih tinggi pada kelompok diet tinggi lemak, dikarenakan besarnya asupan makan berpengaruh terhadap besarnya asupan energi yang kemudian disimpan sebagai lemak dan akhirnya berimplikasi terhadap penambahan berat badan dari hewan coba .

Menurut Faisal Baraas (2003), konsumsi diet yang kaya akan karbohidrat maupun lemak akan menyebabkan peningkatan jumlah lemak yang terdeposit pada jaringan adiposa terutama yang berada dibawah kulit dan di rongga perut (11). Setiap jumlah lemak dan karbohidrat makanan yang berlebihan dan tidak langsung digunakan akan disimpan di jaringan adiposa dalam bentuk trigliserida. Bila diperlukan, trigliserida akan dihidrolisis menjadi asam lemak bebas dan gliserol. Asam lemak bebas ini yang kemudian alami oksidasi untuk menghasilkan energi. Pada umumnya, hanya $3 \%$ dari jumlah glukosa makanan yang dapat disimpan sebagai glikogen di hati dan otot, $30 \%$ disimpan sebagai trigliserida dan $67 \%$ langsung dibakar sebagai energi.

Kelebihan lemak dalam bentuk trigliserida di jaringan adiposa dibawah kulit ataupun di rongga perut inilah yang menyebabkan peningkatan berat badan. Hal ini karena semakin banyaknya jumlah sel lemak di dalam tubuh (hiperplastik) maupun semakin bertambah besar ukuran sel lemak yang ada (hipetropik). Dan sel lemak ini selain bertambah besar juga bertambah padat isinya (12).

Simpanan trigliserida yang berlebihan ini juga sewaktu-waktu potensial sebagai bahan pembentukan VLDL dan LDL di hepar, hal ini jelas beresiko pula terhadap semakin meningkatnya kadar LDL darah yang merupakan faktor resiko terjadinya aterosklerosis.

Menurut James (2005), pada keadaan berat badan yang berlebihan, terjadi penurunan sensitivitas leptin, sehingga sekresi NPY akan meningkat dan nafsu makan juga meningkat (10). Sensitivitas leptin yang menurun ini salah satunya dipengaruhi oleh konsumsi diet tinggi lemak . Sebaliknya, diet tinggi karbohidrat akan meningkatkan kadar leptin, menurunkan nafsu makan dan meningkatkan energi expenditure.

Pada penelitian ini terlihat peningkatan berat badan yang lebih tinggi pada kelompok diet tinggi lemak dibandingkan diet tinggi karbohidrat dikarenakan efek dari pemberian diet tinggi lemak dapat menurunkan kadar hormone leptin, sehingga dengan kadar leptin yang rendah, nafsu makan dan asupan makan pada kelompok ini akan meningkat, dan berat badan juga alami peningkatan yang lebih tinggi dibandingkan kelompok diet tinggi karbohidrat.

\section{Pengaruh Diet Terhadap Kadar Trigliserida Darah Sampel}

Hasil pengujian kadar Trigliserida darah hewan coba untuk kelompok Diet Normal (Xo) menunjukan rata-rata kadar trigliserida $81.28 \pm 17,98 \mathrm{mg} / \mathrm{dl}$. Selanjutnya pada kelompok diet tinggi karbohidrat (X1) menunjukan rata-rata kadar trigliserida $130.28 \pm 42,03 \mathrm{mg} / \mathrm{dl}$ dan nilai tertinggi adalah $169 \pm 43,49 \mathrm{mg} / \mathrm{dl}$ untuk kelompok diet tinggi lemak (X2).

Walaupun dari hasil pemeriksaan kadar trigliserida menunjukan perubahan nilai trigliserida lebih tinggi pada kelompok diet tinggi lemak, tetapi secara statistik dengan menggunakan uji One Way Anova menunjukan adanya perbedaan yang signifikan kadar trigliserida dari masingmasing kelompok $(P=0.011)$. Dan dari masing-masing kelompok tersebut, yang paling menunjukan perbedaan adalah kelompok Diet Tinggi Karbohidrat dan kelompok diet tinggi lemak sebagaimana ditunjukan oleh Post Hoc Tukey Test.

Hasil penelitian diatas menunjukan baik diet tinggi lemak maupun diet tinggi karbohidrat sama-sama meningkatkan kadar trigliserida darah hewan coba pada kedua kelompok diet ini. Hanya saja peningkatan pada kadar Trigliserida terlihat lebih tinggi pada kelompok diet tinggi lemak dibandingkan kelompok diet tinggi karbohidrat. Terjadinya peningkatan kadar Trigliserida yang lebih tinggi pada kelompok diet tinggi Lemak bila dibandingkan diet tinggi Karbohidrat, dikarenakan beberapa faktor. Diantara faktor yang mempengaruhi adalah besar kecilnya asupan energi dari masing-masing kelompok tersebut. Pada 
kelompok diet tinggi Karbohidrat, rata-rata asupan energi lebih kecil yaitu hanya sekitar 55,90 $\pm 30,23$ kal/hari atau $52 \%$ dari kalori pakan yang diberikan sedangkan diet tinggi lemak mencapai $80,6 \pm 13,28 \mathrm{kal} / \mathrm{hari}$ atau $76 \%$ dari total energi pakan yang diberikan.

Peningkatan asupan energi ataupun lemak dari makanan pada kelompok diet tinggi lemak akan menyebabkan peningkatan aktifitas lipogenesis, dan Free Fatty Acid (FFA) atau asam lemak bebas yang terbentuk juga semakin banyak. Selanjutnya terjadilah mobilisasi FFA dari jaringan lemak menuju ke hepar dan berikatan dengan gliserol membentuk Triasilgliserol (TG). Sehingga semakin tinggi konsumsi lemak maka semakin tinggi pula sintesa Triasilgliserol di hepar dan semakin tinggi kadar Trigliserida dalam darah (13).

Peningkatan kadar trigliserida yang terjadi pada kelompok diet tinggi karbohidrat disebabkan karena asupan makanan yang tinggi akan karbohidrat, akan meningkatkan kadar fruktose 2,6 bifosfat sehingga fosfofruktokinase-1 menjadi lebih aktif dan terjadi rangsangan terhadap reaksi glikolisis. Reaksi glikolisis yang meningkat ini akan menyebabkan glukosa yang diubah menjadi asam lemak juga meningkat. Asam lemak bebas inilah yang kemudian bersama-sama dengan gliserol membentuk Triasilgliserol (TG). Sehingga sama halnya dengan diet tinggi lemak, semakin tinggi karbohidrat yang dikonsumsi, akan semakin tinggi pula kadar Triasilgliserol didalam darah (14).

Hiperlipidemia yang salah satunya ditandai dengan kondisi hipertrigliseridemia ini menurut beberapa penelitian merupakan salah satu faktor resiko timbulnya aterosklerosis. Hal ini karena adanya kondisi hipertrigliseridemia akan meningkatkan aktifitas dari CETP (Cholesteryl Ester Transfer Protein). CETP ini akan menukarkan Trigliserida dari VLDL dan IDL, ditukarkan dengan kolesterol yang terdapat pada HDL dan LDL. Sehingga yang terjadi, VLDL dan IDL menjadi kaya akan kolesterol, sedangkan HDL dan LDL menjadi kaya akan Trigliserida atau dikenal sebagai Lipoprotein kaya trigliserida (TGrL). (15)

Menurut Turtle et al (1999), Trigliserida yang terdapat pada TGrL ini kemudian dihidrolisa menjadi partikel kecil padat atau yang lebih dikenal dengan small dense LDL (15). Small Dense LDL inilah yang lebih bersifat aterogenik dibandingkan LDL karena selain mudah mengalami oksidasi, partikel ini juga lebih mudah melakukan penetrasi terhadap dinding arteri. Dan karena partikelnya yang kecil, menyebabkan partikel LDL ini tidak bisa lagi dikenali reseptornya, sehingga semakin tinggi kadar trigliserida dalam darah seperti yang terjadi pada kelompok diet tinggi lemak dan diet tinggi karbohidrat, semakin tinggi pula resiko terjadinya aterosklerosis.

Peningkatan kadar trigliseride ini juga akan meningkatkan katabolisme dari HDL. Semakin rendah HDL, maka semakin banyak kolesterol yang beredar di darah yang tidak terangkut kembali ke hati, dan semakin tinggi pula resiko terjadinya aterosklerosis.

Demikian halnya dengan penelitian ini, dimana peningkatan kadar trigliserida ini juga bisa dipengaruhi oleh kadar insulin plasma yang walaupun tidak secara langsung dilakukan pemeriksaan terhadap kadar insulin plasma dari masing-masing kelompok percobaan, tetapi kondisi resistensi insulin bisa muncul sebagai akibat kondisi hiperglikemia yang berkepanjangan. Pada kelompok hewan coba yang diberi diet tinggi karbohidrat dan kelompok yang diberi diet tinggi lemak, setelah dilakukan pemeriksaan kadar gula darah puasa, menunjukan adanya peningkatan dibandingkan kelompok diet normal/ kontrol. Dan setelah dilakukan uji statistik, menunjukan adanya perbedaan bermakna dari kadar gula darah antar kelompok tersebut. Peningkatan kadar gula darah paling tinggi nampak pada kelompok diet tinggi karbohidrat.

Pemberian diet tinggi karbohidrat menyebabkan peningkatan kadar glukosa darah lebih cepat bila dibandingkan diet tinggi lemak, peningkatan kadar glukosa darah ini atau sering disebut dengan hiperglikemia, menyebabkan keadaan hiperinsulinemia, kondisi ini lama kelamaan akan menyebabkan resistensi insulin. Seperti disebutkan diatas, resistensi insulin akan menyebabkan penurunan aktivitas dari enzim lipoprotein lipase. Semakin rendah aktivitas enzim Lipoprotein Lipase ini, akan meningkatkan kadar trigliserida dalam darah.

Hanya saja, pengaruh pemberian diet tinggi karbohidrat secara langsung terhadap peningkatan kadar Triasilgliserol lebih lambat bila dibandingkan kelompok lemak selain karena asupan makan yang lebih kecil juga karena proses yang terjadi pada kelompok diet tinggi karbohidrat adalah melalui proses hiperglikemia lebih dahulu.

Pemberian diet tinggi karbohidrat yang melebihi $80 \%$ total kalori pada penelitian ini membawa pengaruh pada peningkatan kadar trigliserida. Seperti halnya penelitian yang dilakukan oleh Samaha et al bahwa ternyata karbohidrat yang selama ini masih dianggap sebagai komponen makanan yang aman sehingga direkomendasikan dalam prosentase yang lebih tinggi, tetapi akhirakhir ini mulai diperhitungkan peranan karbohidrat tersebut dengan terjadinya aterosklerosis. Kenyataan bahwa angka kejadian penyakit kardiovaskuler juga cukup tinggi di negara-negara yang kandungan utama dari makanannya adalah karbohidrat. hal ini berarti bahwa konsumsi tinggi karbohidrat juga bisa bersifat aterogenik apabila dikonsumsi dalam jumlah berlebihan.

\section{Pengaruh Diet Terhadap Kadar HDL Darah Sampel}

HDL (Hight Density Lipoprotein) dikenal sebagai lemak baik. HDL berfungsi membawa kolesterol bebas dari jaringan perifer menuju hati. Kolesterol ini diubah menjadi kolesterol ester yang sebagian dipindahkan ke VLDL 
melalui bantuan enzim CETP dan dikembalikan lagi ke hati oleh IDL dan LDL. Hati akan memanfaatkan kembali kolesterol ini untuk diubah menjadi garam empedu atau langsung mengsekresikan ke dalam empedu (14).

Hasil pengujian kadar HDL darah hewan coba untuk kelompok Diet Normal (Xo) menunjukan rata-rata kadar HDL 32,7 $\pm 3,86 \mathrm{mg} / \mathrm{dl}$. Selanjutnya pada kelompok diet tinggi karbohidrat (X1) menunjukan rata-rata kadar HDL $38,4 \pm 2,76 \mathrm{mg} / \mathrm{dl}$ dan $34,2 \pm 7,13 \mathrm{mg} / \mathrm{dl}$ untuk kelompok diet tinggi lemak (X2).

Pada penelitian ini, hasil pemeriksaan menunjukan rata-rata kadar HDL paling kecil (penurunan HDL paling besar) ada pada kelompok diet normal/ kontrol, diikuti dengan kelompok diet tinggi lemak. Sedangkan kelompok diet tinggi karbohidrat rata-rata kadar HDLnya masih cukup tinggi.

Hal yang mungkin terjadi adalah, penurunan HDL paling banyak pada kelompok normal dan kelompok diet tinggi lemak disebabkan lebih tingginya asupan makanan dari kedua kelompok tersebut bila dibandingkan dengan kelompok diet tinggi karbohidrat, sehingga peranan banyak sedikitnya kalori yang masuk lebih cepat memberikan makna terhadap penurunan HDL. Sedangkan pada kelompok diet tinggi karbohidrat, penurunan HDL lebih lama prosesnya. Selain itu, peningkatan kadar trigliserida yang lebih tinggi pada kelompok diet tinggi lemak menyebabkan penurunan HDL yang lebih banyak pada kelompok ini bila dibandingkan dengan kelompok diet tinggi karbohidrat. Walaupun begitu, setelah dilakukan uji lanjut menggunakan Uji Post Hoc Tukey, hasil yang didapat adalah tidak ada perbedaaan yang signifikan dari ketiga kelompok diet tersebut $(P>0.05)$.

Menurut Pastore R (2003), berdasarkan penelitian yang dilakukannya menyebutkan bahwa diet tinggi karbohidrat dan diet asam lemak jenuh akan menyebabkan penurunan pada HDL kolesterol (16). Lebih spesifik dikatakan, bahwa Diet tinggi karbohidrat dan diet asam lemak jenuh ganda akan menyebabkan penurunan pada Apolipoprotein A-1 yang merupakan penyusun utama HDL. Sedangkan pemberian diet tinggi asam lemak tidak jenuh tunggal akan meningkatkan Apolipoprotein A-1.

Apolipoprotein A-1 sebagai salah satu komponen utama dari HDL berfungsi menurunkan pembentukan LDL teroksidasi. LDL teroksidasi ini akan menyebabkan peningkatan resiko terjadinya aterosklerosis. Sehingga semakin tinggi $\mathrm{HDL}$, semakin melindungi LDL terhadap terjadinya oksidasi karena pengaruh radikal bebas.

Bisa dikatakan bahwa baik pemberian diet tinggi lemak terutama lemak jenuh maupun diet tinggi karbohidrat sama-sama beresiko menurunkan kadar HDL kolesterol (17). Berdasarkan penelitian ini diet tinggi karbohidrat tidak terbukti secara statistik dapat menurunkan kadar HDL lebih banyak dibandingkan dengan diet tinggi lemak. Akan tetapi hal yang harus diperhatikan menurut Stephen, 2003 adalah bahwa rasio antara Trigliserida dan HDL merupakan parameter yang lebih baik untuk mengetahui kemungkinan serangan penyakit jantung daripada perbandingan antara LDL dengan HDL (5).

\section{KESIMPULAN}

1. Kadar trigliserida darah tertinggi terdapat pada kelompok diet tinggi lemak yaitu $169 \mathrm{mg} / \mathrm{dl}$, diikuti diet tinggi Karbohidrat sebesar 130,2 mg/dl dan yang terendah adalah diet normal yaitu $81.2 \mathrm{mg} / \mathrm{dl}$. statistik terhadap kadar Trigliserida serum antar kelompok diet menunjukan perbedaan bermakna $(p=0,011)$

2. Kadar HDL terendah adalah Diet Normal yaitu 32,7 $\mathrm{mg} / \mathrm{dl}$, diikuti diet Tinggi Lemak $34,2 \mathrm{mg} / \mathrm{dl}$ dan yang tertinggi adalah diet Tinggi karbohidrat yaitu $38,4 \mathrm{mg} / \mathrm{dl}$. Berdasarkan uji statistik untuk kadar HDL antar kelompok diet menunjukan tidak adanya perbedaan yang signifikan dari tiap perlakuan $(P=0,111)$.

3. Diet tinggi karbohidrat dapat berresiko terhadap kenaikan kadar trigliserida .

\section{SARAN}

1. Pola makan tinggi karbohidrat dari makanan kita seharihari perlu diperhatikan, karena selain diet tinggi lemak, ternyata diet tinggi karbohidrat juga mempunyai sifat aterogenik yakni dapat menaikkan kadar Trigliserida darah.

2. Berdasarkan penelitian yang dilakukan pada Rattus Novergicus Galur Wistar komposisi karbohidrat yang aman yaitu dibawah $80 \%$ atau $68,99 \%$ dari total kalori per hari, lemak $9,73 \%$ dan Protein $21,26 \%$ total kalori per hari.

\section{DAFTAR KEPUSTAKAAN}

1 Murjiah Dinarto. Nutrisi Pada Penyakit Vaskular Aterosklerotik. Didalam: Pegangan Penatalaksanaan Nutrisi Pasien. Jakarta: PDGMI ; 2000; 86-91.

2 Sastroamidjojo. Pegangan Penatalaksanaan Nutrisi Pasien. Jakarta: PDGMl; 2000.

3 Murray RK, Graaanner DK, Mayes PA, Rodwell VM. Biokimia Harper. terjemahan oleh Alexander dan Andry Hartono; Jakarta: EGC; 2003. 
4 Samaha FF. A low Carbohydrate as Compared With A Low fat Diet in Severe Obesity". N.England Journal Medicine 2003; 348:21, 2074-2081.

5 Stephen DS. "Triglycerides and Your health. 2003 December 2003. [accessed 29 May 2004] http://www.heartcenteronline.com/myheartdr/common/articles.cfm?ARTID=504

6 Ibnu Subiyanto. Metodologi Penelitian. Yogyakarta: UPP Akademi manajemen YKPN; 2000

7 Adjie S. Rancangan Percobaan Praktis untuk Bidang Pertanian. Yogyakarta: Kanisius; 1998

8 Bresnahan J. Biological and Physiological Data on Laboratory Animal. Jurnal 15.Kansas State University; 2004

9 Bruckdorfer KR. Obesity: Endocrine Control Of Appetite. 2005 [accessed 14 May 2005 ] http://www.rfc.ucl.ac.uk/departments/Biochemistry/docs/42-Endoobesity2005.ppt

10 James J.M. Leptin: Strategies for Succes in Weight management. 2005

11 Faisal Baraas. Mencegah Serangan Penyakit Jantung dengan menekan kolesterol. Jakarta: Kardia Iqratama; 2003

12 Agus K. Dasar-dasar Ilmu Gizi. Malang: UMM Pres; 2004

13 Myers. Interrelationship between Carbohydrate and lipid Metabolism"Biological Chemistry, California State University, Long Beach; 2003

14 Marks DB. PHd. Biokimia Kedokteran Dasar. Jakarta: EGC; 2000

15 Turtle J. Diabetes in the Millenium: Lipid Metabolism in Diabetes (Chapter 32), Sydney, Australia 1999; 317-327.

16 Pastore R. Getting to the heart of the matter. 2003 [accessed 6 June 2005] http://metabolism.com/healthbytes.

17 Ginsberg HN. Nonpharmacologic management of low levels of High-density lipoprotein cholesterol. Am J. Cardiol 2000; 86:41L-5L. [accessed 8 June 2005 ] http://www.aafp.org/afp/20010615/tips/2.html 